\title{
SOCIALLY RESPONSIBLE LOGISTICS IN OF PUBLIC SERVICES' AREA
}

\author{
SABINA KAUF \\ Opole University, POLAND \\ e-mail: skauf@uni.opole.pl
}

\begin{tabular}{|c|c|}
\hline $\begin{array}{l}\text { RECEIVED } \\
\text { ACCEPTED }\end{array}$ & $\begin{array}{l}13 \text { July } 2017 \\
15 \text { December } 2017\end{array}$ \\
\hline $\begin{array}{l}\text { JEL } \\
\text { CLASSIFICATION }\end{array}$ & L20 \\
\hline KEYWORDS & CSR, public services logistics, public orders \\
\hline ABSTRACT & $\begin{array}{l}\text { In this article the issues of social responsibility and necessity of its implementation in public sector have } \\
\text { been taken on. We've tried to answer the question: what criteria should be taken into account in bargaining } \\
\text { procedures so public task could be completed concordantly with social responsibility rules and in what way } \\
\text { logistic can support completing public tasks. It's been said that main criteria consist of ecological and social } \\
\text { aspects influencing for example improvement of quality of life, solving of social issues and abiding law by } \\
\text { executors. Moreover we came to the conclusion that logistic area with its coordinating function is the most } \\
\text { predestine for giving public services. }\end{array}$ \\
\hline
\end{tabular}

\section{Introduction}

Meaning of social responsibility and economical aspects is constantly growing. More and more often it is a basis of building mutual trust and transparent relationships between external and internal buyers. Nowadays being socially and responsibly active should occur among not only economic units, but also public sector 
ones, ${ }^{1}$ to which social responsibility is a main goal. It is a consequence to a community, entered in essence of its functioning. Any tasks completed through public services have a function to satisfy social or local needs (Tribunal of Constitution, 1994, pp. 191-200). That's why it can seem like the public sector should be socially responsible and it does not has to undertake additional and very expensive activities to prove that fact.

However from the concept of country that guarantees responsibility for delivering mutual good with synchronic resignation from independent performance of public tasks says that. National services don't have to or even should not complete all of the tasks independently. As a natural consequence of higher mentioned data is commitment private sector in implementation of public tasks as tender procedures. Main meaning is transcribed to expenses so social and environmental aspects are neglected. It is happening even though European Union guidelines ${ }^{2}$ and amendment of acts about law of public orders in membership countries. Then the questions are created:

- what criterion should be made in accordance with rules of social responsibility of public orders to make choice of the best solution possible,

- in what way responsible Logistics can support completing public tasks.

Those questions are a starting point of consideration of these assumptions, and its goal is to show dependencies in implementing social responsibility in area of public services logistics. ${ }^{3}$

\section{Validity of implementation of concept CSR in public sector}

Concordantly with The European Union green paper CSR is a concept of voluntary consideration of social and ecological aspects in directing commercial actions and contacts with surroundings (Green Paper..., 2008). Its implementation lets to improve competitiveness in area of expenses and financial productivity, it helps to increase effectiveness of using human capability, is an engine of innovation, simplifies management of risk and improves image of the company in customers sight (Communication..., 2008).

The concept of "Corporate Social Responsibility” shows that it is a concept addressed to economical units. Adjective "Corporate”, because of its entrepreneurial connotation, from public sector point of view, doesn't seem to be very adequate. It results from a goal, which is to guarantee correct functioning of society. Without existing public sector, social services would be offered on unsatisfactory level in area of quantity, quality and price. This assumption excludes economic activity, which may be leader only if it finds explanations in social goals. However ineffectiveness of public sector leaded to change the ways of thinking and managing. They deployed concept of New Public Management, which means to commercialize public sector and managers way to managing it. This means that this sector has its business rules. Enterprising character can be seen in responsibility for good and effective delivery of services which means creating their availability and openness and low cost of delivering them (Wodecka-Hyjek, 2008, p. 247). It seems to explain necessity to implementation of CSR public sector.

Social responsible actions are used to legitimization of society, and main goal of CSR is showing that any entrepreneurial actions, in ethical, social and ecological aspect ale useful for society and their production is

\footnotetext{
1 Through the public sector we understand local government units and other public benefit organizations.

2 In 2005, the European Commission published a handbook highlighting the need to integrate sustainable development into public procurement, and in 2008 Sustainable Consumption and Production and Sustainable Industrial Policy which contains the necessary guidelines to help reduce the pressure of the economy and society on the environment.

${ }^{3}$ Public service logistics is understood as temporal-spatial transformation of goods related to the realization of public tasks. Logistics is also an important part of cross-sectoral coordination (private, public and non-governmental sectors) (Kauf, 2014, p. 46).
} 
responsible (Kuhlen, 2005, p. V). Knowing that we should say that actions helping to deliver values to buyers in responsible way should be leader by those units which feel the lack of legitimization. For public organizations, social responsibility is a main goal, which make them have democratic card. So we can't say they don't have social card. Possible lack in this area come from deficit of communication. If it is like that then we should ask a question: why implementation of the Social Responsibility concept is necessary to public sector? The answer seems to be easy. Public sector is quitting independent implementation of public tasks more and more often. It is giving its entrepreneurship to private units in which legitimization deficit can be bigger. Some aspects can be worrying for example conditions of work which in case of realization of tasks by external units can get worse and lead to dissatisfaction and objection of society. That is why decisions of public sector units about choosing external contractor should be addicted to for example consequences for labor and quality of provided services (Amirkhanyan, Kim, Lambright, 2007, p. 703).

Connections of public sector with economical one are pointing the necessity to create affiliate multisector relationships. Only then cooperation will elaborate, giving satisfaction to both sides and advantages to local societies. This direction is recommended by World Business Council for Sustainable Development in document „Vision 2050. The new agenda for business". They pointed what actions should be taken into account to until 2050 „around 9 billion people live well, and within the limits of the planet”. In the document it was emphasized that an important factor determining balanced development is cooperation between sectors, consisting of mutual decision making and mutual responsibility for taken actions in all involved units. In this context correctly understood Corporate Social Responsibility can help with completing public tasks.

In harmony with data above public sector should be responsible for creating conditions of effective abiding the law, following the procedures, preventing corruption and make ethical actions common. In the matter of social and environmental responsibility, public sector also fulfills part of middleman between business world and society. Its actions in this area should concentrate on creating good conditions to choose by economical units (and not only) voluntary commitment for balanced development. Main goal of a public sector $\mathrm{i}$ also providing effective coordination of actions in this area and creating a platform to exchange knowledge and experiences. As a consequence we can highlight four main functions, which public sector can make in relation to Social Responsibility Concept (Tenta-Skwiercz, 2009, p. 111):

- educational - promoting concept of CSR,

- coordination- supporting structuring and negotiating programs of CSR,

- motivational - making it common to give incentives to representatives of economic area to taking social responsible actions,

- integrative - creating conditions to cooperation between sectors and building public-private partnerships.

From a point of view of those considerations the most interesting is the last function that refers to deputing implementation of public tasks to external units. Among them the most determined ones seem to be logistic operatives because logistics with its coordination function creates the biggest possibilities of optimal forming joints between public and economical area. Logistic operatives can take on various tasks which area is unlimited. They can provide classical (transport, warehouse jobs, order picking), consulting, financial and personal services. They can also produce public tasks (like export of waste) and use public sector logistically (feed of the hospitals). Use of logistics to complete public tasks requires creating proper procedure of transmitting production of tasks to external units. Those procedures are public orders. 


\section{Public orders as the social base of responsible Logistics of public services}

From the principle of subsidiarity it results that public sector should concentrate on its main activity and commercialize the rest of it. This creates possibilities to develop logistic public services. Transferring implementation of public benefits to logistic operatives makes it real to implement CSR concept to the public sector. It comes from a fact that thanks to Logistics initiative, some climate conferences have been and are organized where problems of development, responsibility and ethics are discussed. In implementation of logistic processes they started to look for pro-ecological solutions and taking into account results of logistic actions for the environment so the society could find their reflection in Logistics Social Response (Carter, Jennings, 2002). Coordination function coming from idea of Logistics lets to creating partnerships between sectors and promoting way of cooperation that lets to mutual determining goals taking into account rules of balanced development and social good.

Because of public paymasters decisions are made by political and administrative teams, they describe conditions of public-private contracts. Because of long term character of public tasks should have form of contracts with limited time of duration, depending on type of contract and quality of services (Budäus, 2005, pp. 11-18). As a consequence public sector can get logistic operatives to completing public tasks on regulated concurrency rules based on act about law of public orders. Procedure of a choice of contractor consists of two levels. Allowance $\mathrm{g}$ to the second requires from potential entrepreneurs completing formal requirements and having attributes to predispose them to completing the task, for example; knowledge, experience, technical and human potential and proper financial conditions. In second level choice of the most advantageous offer is being made for example; the cheapest or the quickest. These criteria shouldn't by the only ones because they can lead to short termed advantages (Kauf, 2008, p. 265).

From the point of view of social responsibility the key factors of choosing logistic contractor should be environmental policy and social aspects. Those should be literally concluded in tender conditions. Only those completed ones will be environmental and social provisions coming from rules in Law of public orders. Those modeled ones in the same way as polish law system has been introduced in July 2016. At that time an act about changing the act of Law of public orders (Dz.U. 2016, poz. 1020) has been approved, it implemented guidelines of European Union Parliament and European Council from February 2014. Those guidelines have become very effective tool socially responsible of public orders which means that those which respect human and labor rights, support social attachment and social economy and promote mutual equal chances; availability and universality of public orders. Idea of taking into account social aspects in European Union forms Strategy called 'Europe 2000' for intelligent and balanced development beneficial for social connection. Its main goal is to support; economy of the effective use of resources, more environmental friendly and beneficial for social connection. On the other hand idea of consideration of social aspects on national level forms for example Strategy 'Efficient Nation2020'. Concordantly with its rules, goal of effective management of physical and financial resources, public sector should spread already existing law results considering social issues (social clause)and ecological aspects (green public orders) in tender procedures.

Social implementation of responsibility to public services Logistics should be precluded with analysis of antisocial influence arise from ordering process and identification of social areas if interest. Also important are partnership relations with contractors (logistic operatives). Respecting social dimension in choosing logistic contractor it can find their reflection in preferring units that care about safeness and health of their employees, promoting an employment of workers from nearest area, those who follow basic work standards, fair wages or 
equality of chances. Eliminating those who do not complete those requirements coming from law of work and social or health securities of hired workers .

New law regulations let to choose those logistic partners who are directing themselves not only with economic issues but social ecological. Concordantly with amendment of act law of public orders the criteria of assessment of offers is price, or expenses or different criteria related to unit of order. This means that we should choose the most economically efficient offer which doesn't mean the same as the cheapest one. As an effect it will let to for example buy more expensive but more environmentally friendly and cheaper in exploitation ways of public communication (smaller use of fuel) or devices used in implementation of infrastructures investments. Environmentally friendly product, even more expensive one, in longer perspective can become cheaper one or equally cheap as the product that we used until now. Explanation of a choice of the most economically friendly offer in this case would be Life Cycle Cost (LCC) analysis. Defines it Directive 2014/24/eu of the European Parliament and of the Council at art. 2 p. 20: „life cycle all consecutive and/or interlinked stages, including research and development to be carried out (...) throughout the existence of the product (...). According to art.91 ust. 3c of act of Public Orders Law these are the costs connected to buying a product, its use (use of energy and different resources), maintenance and with drawl of exploitation (costs of recycling).

Strong connections and dependencies between sectors, especially their integration and merging in process of implementing public tasks cause that results of actions of one units have very strong influence on reputation of others. Facilitation of elimination of risk transpires in order to widening responsibility. In area of Logistics and management of chain of deliveries, widening of responsibility is described as corporate social watchdog and it stands to taking over dominant position in chain of deliveries by a company or leading corporation which describes standards for their suppliers directed by their behaviors in way of their values and expectations. In case of implementation of public services role of corporate social watchdog takes off the public administration and standards are described in order to tender procedures. Moreover public sector takes paternalistic responsibility for their entrepreneurs because from power of law, the responsibility for availability of services is in his hands. In case of not completing the task by a private unit, public contractor who is committed to deliver a service anyway. This causes that division of risk is asymmetric. Concordantly with the concept of corporate social watchdog relationships between public administration and public services entrepreneurs are main point of interest (Faisal, Banwet, Shankar, 2006, p. 535). As an effect, disputing pursuance to partnership relations between sectors, some differences in tender forces, which is usually at public sector side, are having place. In many cases entrepreneurs understand reasons of existing this inequality and are able to accept it.

Above data directs to transformation of CSR concept in direction to its domination not only in economic units but also whole width of connection between public and private sector. Necessity to socially forming of responsible logistic of public services comes from expectations of the society. Those apply to making only smart and necessary purchases for example products that in possibly smallest point having impact on environment and taking into account socially-economical results of shopping decision.

\section{Summary}

Based on made studies it emerges that among main criteria , which should be implemented with harmony with social responsibility rules in public orders are; ecological aspects (solutions that in whole cycle of products life have 
the smallest negative impact on natural environment) and social (employing disabled and people from the nearest area, guarantee of minimal wages). Taking them into account leads to many positive effects:

- improving quality of life, health and satisfaction of citizens - lowering level of global warming,

- reduction of expenses- for example energy-saving results,

- solving social issues-for example influence on policy of employment in the nearest area,

- control of following the law by entrepreneur - for example unfair actions to employees,

- image advantages and demonstration of social sensitivity.

Social responsibility more and more often is seen as one of key megatrends of logistics that's why it can support implementation of public tasks in important way. Anchored in logistics function of coordination, lets to optimize connections between public area and economic one. Logistic operatives can deliver almost unlimited variety of services, from classical ones (transport, warehouse jobs), through consulting, financial, personal, to public tasks (export of waste) and logistic services (supplying hospitals).

\section{References}

Amirkhanyan, A.A., Kim, H.J., Lambright, K.T. (2007). Putting the Pieces Together: A Comprehensive Framework for Understanding the Decision to Contract Out and Contractor Performance. International Journal of Public Administration, 6 (30).

Budäus, D. (2005). Public Private Partnership - Kooperationsbedarfe, Grundkategorien und Entwicklungsperspektiven. In: D. Budäus (ed.), Kooperationsformen zwischen Stadt und Markt. Baden-Baden.

Carter, C.R., Jennings, M.M. (2002). Logistics Social Responsibility: An Integrative Framework. Journal of Business Logistics, 1 (23).

Communication from the Commission to the Council, the European Parliament, the European Economic and Social Committee and the Committee of the Regions (2008). Brussels.

Directive 2014/24/eu of the European Parliament and of the Council (2014).

Dz.U. (2016). Prawo Zamówień Publicznych, Dz.U. poz. 1020.

Faisal, M., Banwet, D., Shankar, R. (2006). Supply chain risk mitigation: modelling the enablers. Business Process Management Journal, 4.

Green Paper (2008). Promoting The European framework for the Corporate Social Responsibility, European Commission 2008-SEC (2008)2853. Brussels.

Kauf, S. (2008). Partnership as a tool in local development. In: L. Jakubów (ed.), Cooperation of public services, universities and companies in local development. Wrocław: WSZ „Edukacja”.

Kauf, S. (2014). Public logistics - development and determinants. In: A. Bujak, M. Paradowska (eds.), Challenges and Conceptions in Contemporary Logistics (pp. 45-57). Sciencific notebooks of WSB Wrocław, 1 (39).

Kuhlen, B. (2005). Corporate Social Responsibility (CSR). Die ethische Verantwortung von Unternehmen für Ökologie, Ökonomie und Soziales. Baden-Baden.

Savas, E.S. (2000). Privatisation and Public-Private Partnership. New York.

Teneta-Skwiercz, D. (2009). Role of the government administration in area of development CSR w Poland. In: Z. Pisz, M. Rojek-Nowosielska (eds.), Socially responsible of business. Controversial conditions, good and bad practices. Wrocław: Wrocław University of Economics.

Tribunal of Constitution (2004), act from 27.09.1994, W 10/93, OTK 1994, part. II, p. 191 and others.

WWodecka-Hyjek, A. (2008). Odpowiedzialność społeczna w administracji publicznej. In: W. Błaszczyk (ed.), Nurt metodologiczny w naukach o zarządzaniu - w drodze ku doskonałości. Łódź: Wydawnictwo Uniwersytetu Łódzkiego.

Cite this article aS: Kauf, S. (2018). Socially responsible logistics in of public services' area. European Journal of Service Management, 2 (26), 131-136. DOI: 10.18276/ejsm.2018.26-16. 